\title{
Host-Pathogen Interaction in Fusarium oxysporum Infections: Where Do We Stand?
}

\author{
Amjad M. Husaini, ${ }^{1,2,+}$ Aafreen Sakina, ${ }^{1}$ and Souliha R. Cambay ${ }^{1,3}$ \\ ${ }^{1}$ Genome Engineering Lab, Division of Plant Biotechnology, SKUAST-K, Shalimar, Jammu \& Kashmir-190025, India; ${ }^{2}$ The Plant \\ Chemetics Laboratory, Department of Plant Sciences, OX1 3RB South Parks Road, University of Oxford, U.K.; and ${ }^{3}$ Division of \\ Genetics, Indian Agricultural Research Institute, Pusa, New Delhi-110012, India
}

Accepted 13 March 2018.

\begin{abstract}
Fusarium oxysporum, a ubiquitous soilborne pathogen, causes devastating vascular wilt in more than 100 plant species and ranks 5th among the top 10 fungal plant pathogens. It has emerged as a human pathogen, too, causing infections in immune-compromised patients. Therefore, it is important to gain insight into the molecular processes involved in the pathogenesis of this transkingdom pathogen. A complex network comprising interconnected and overlapping signal pathways-mitogen-activated protein kinase signaling pathways, Ras proteins, G-protein signaling components and their downstream pathways, components of the velvet $(\mathrm{LaeA} / \mathrm{VeA} / \mathrm{VelB})$ complex, and cAMP pathways-is involved in perceiving the host. This network regulates the expression of various pathogenicity genes. However, plants have evolved an elaborate protection system to combat this attack. They, too, possess intricate mechanisms at the molecular level which, once triggered by pathogen attack, transduce signals to activate defense response. This review focuses on understanding and presenting a wholistic picture of the molecular mechanisms of $F$. oxysporum-host interactions in plant immunity.
\end{abstract}

Fusarium is a cosmopolitan genus of filamentous ascomycete fungi (Sordariomycetes: Hypocreales: Nectriaceae) that resolves into a monophyletic group encompassing all economically important Fusarium spp. Nine of the species resolve into 20 monophyletic species complexes that include as many as 60 species. Fusarium oxysporum is a ubiquitous, soilborne pathogen which causes devastating vascular wilt in more than 100 plant species and poses a serious threat to a wide range of economically important crops such as banana, cotton, melon, and tomato (Gordon and Martyn 1997) (Table 1). It is considered a species complex in which different species can be pathogenic toward different hosts or nonpathogenic. Isolates pathogenic on the same host are grouped into the same forma specialis (e.g., F. oxysporum f. sp. lycopersici for tomato pathogens) and the general mode of infection for all formae speciales is similar. Devastating vascular wilt caused by $F$. oxysporum has become a menace to farmers worldwide, curtailing the production of economically important crops. Expanding the host range by horizontal acquisition of

${ }^{\dagger}$ Corresponding author: Amjad M. Husaini;

E-mail: amjadhusaini@ skuastkashmir.ac.in

Funding: This work was supported by the Department of Biotechnology, Ministry of Science and Technology.

() 2018 The American Phytopathological Society lineage-specific (LS) genomic regions between different species of $F$. oxysporum makes the pathogen even deadlier. It ranks 5 th among top 10 fungal plant pathogens (Dean et al. 2012) and has also emerged as a human pathogen (Nucci and Anaissie 2007).

F. oxysporum initially penetrates roots asymptomatically. It subsequently colonizes vascular tissue and triggers massive wilting, necrosis, and chlorosis of aerial plant parts. Compared with other Fusarium spp., F. oxysporum isolates exhibit a high degree of host specificity (Ma et al. 2013). A complex network comprising interconnected and overlapping signaling pathways is activated once $F$. oxysporum recognizes a host in its vicinity. These pathways include mitogen-activated protein (MAP) kinase signaling pathways (Di Pietro et al. 2001), Ras proteins, G-protein signaling components and their downstream pathways (Jain et al. 2002, 2003, 2005; Martínez-Rocha et al. 2008), components of the velvet (LaeA/VeA/VelB) complex (López-Berges et al. 2013), and cAMP pathways (Jain et al. 2005). The components of different pathways regulate expression of different pathogenicity genes conferring virulence to $F$. oxysporum.

Some plants have evolved elaborate and sensitive protection systems to combat the attack of $F$. oxysporum, which involve intricate molecular mechanisms that are triggered by pathogen attack and which transduce signals to activate defense responses, as discussed below. Model crops Arabidopsis thaliana and tomato have been used as tools to obtain insight into the gene networks that regulate resistance to $F$. oxysporum (BerrocalLobo and Molina 2008; Diener and Ausubel 2005). Therefore, effective management of the wilt diseases will require a thorough knowledge and understanding of the molecular mechanisms involved in the pathogenesis of this transkingdom pathogen as well as discerning the nature of resistance in resistant cultivars. This review summarizes aspects of $F$. oxysporum genetics and the plant-signaling networks that successfully circumvent wilt.

\section{PATHOGEN PERCEPTION AND DEFENSE}

Plants recognize Fusarium attack for effective defense. They have the competence to perceive an arsenal of nonself molecules emanating from $F$. oxysporum as well as endogenous signals originating from their own cell walls by surveillance of cellular intactness. Mechanisms underlying host defense are different in different crops. The plant cell wall is the first barrier that F. oxysporum encounters during attack and this barrier defines the primary or basic strength of plants to encounter and restrict it. In some resistant banana varieties, it is the cell wall that imparts resistance to strains of $F$. oxysporum Foc TR4 before colonization ( $\mathrm{Li}$ et al. 2012). In resistant varieties of banana, the numbers of spores attached to roots are substantially low 
compared with susceptible varieties. Several genes such as 3-deoxy-d-arabino-heptulosonate-7-phosphate synthase, 4coumarate-CoA ligase, polyphenol oxidase, glutathione Stransferase (GST), UDP-glucuronic acid decarboxylase, and cellulose synthase, which act at different steps of the shikimate phenylpropanoid-lignin and cellulose biosynthesis pathways, are reported to strengthen the cell wall and are upregulated in resistant varieties of banana ( $\mathrm{Li}$ et al. 2012). The strengthened cell wall is a possible reason for the reduced spore attachment and enhanced resistance ( $\mathrm{Li}$ et al. 2012).

Plants recognize microbial surface-derived molecules called pathogen- or microbe-associated molecular patterns (PAMP or MAMP, respectively) through pattern recognition receptors (PRR). Binding of PAMP to distinct PRR activates these receptors and relays the signal downstream to convergent signaling pathways triggering broad-spectrum immunity (Muthamilarasan

Table 1. Some of the major formae speciales of Fusarium oxysporum, illustrating its wide host range

\begin{tabular}{|c|c|c|c|}
\hline Number & F. oxysporum & Crop infected & Symptoms \\
\hline 1 & f. sp. lycopersici & Tomato & $\begin{array}{l}\text { Yellow leaves, vascular discoloration, leaf chlorosis and wilted } \\
\text { plants }\end{array}$ \\
\hline 2 & f. sp. melonis & Melon & $\begin{array}{l}\text { Yellowing and death of lower leaves, death of branches, brown } \\
\text { lesions with dark gum exudates, white mycelial growth on } \\
\text { surface of fruit, necrosis, and vine death }\end{array}$ \\
\hline 3 & f. sp. phaseoli & Bean & $\begin{array}{l}\text { Wilting, vascular discoloration, chlorosis, dwarfism, premature } \\
\text { defoliation, and plant death }\end{array}$ \\
\hline 4 & f. sp. radicis-lycopersici & Tomato & $\begin{array}{l}\text { Swelling at the crown, orange and brown lesions at the crown, } \\
\text { decay and withering of lower stem, root rot, and plant wilting }\end{array}$ \\
\hline 5 & f. sp. cubense & Banana & $\begin{array}{l}\text { Reddish-brown discoloration of the rhizome, bright yellow } \\
\text { leaves and subsequent collapsing around the pseudostem, and } \\
\text { pseudostem wilt }\end{array}$ \\
\hline 6 & f. sp. coglutinans & Cabbage & $\begin{array}{l}\text { Yellowing of lower leaves, stunting of plant, distortion of leaves, } \\
\text { wilting and death of plant, and vascular discoloration }\end{array}$ \\
\hline 7 & f. sp. citri & Orange & $\begin{array}{l}\text { Discoloration of vascular tissue, root rot in seedlings, wilt, } \\
\text { chlorosis, and epinasty of the young leaves (early symptoms). } \\
\text { Brown discoloration of vascular tissue, wilting, and death of } \\
\text { plant (late symptoms) }\end{array}$ \\
\hline 8 & f. sp. ciceris & Chickpea & $\begin{array}{l}\text { Yellowing and chlorosis of lower leaflets, initial rootlet } \\
\text { yellowing followed by gradual browning of roots, retardation } \\
\text { of root growth and branching. Chlorosis of aboveground plant } \\
\text { parts and wilting }\end{array}$ \\
\hline 9 & f. sp. cepae & Onion & Basal and root rot that later spreads to bulb scales \\
\hline 10 & f. sp. cannabis & Cannabis sativa & $\begin{array}{l}\text { Foliage turns yellow, wilts, dries up, and hangs on the plants. Dark- } \\
\text { brown discoloration of vascular tissue. Infected plants are killed }\end{array}$ \\
\hline 11 & f. sp. canariensis & Date palm & $\begin{array}{l}\text { Frond death from oldest to newest, then frond turns brown or } \\
\text { dies, mostly on one side of the rachis (one-sided or both sided). } \\
\text { Brown strip on the surface of the petiole or rachis } \\
\text { Longitudinal section of frond has a brown strip externally that } \\
\text { will show internal vascular streaking or discoloration }\end{array}$ \\
\hline 12 & f. sp. asparagi & Asparagus & $\begin{array}{l}\text { Yellow and wilted shoots. Stunted shoot growth and shoot death. } \\
\text { Vascular discoloration. Reddish-brown elliptical lesions } \\
\text { present at the base of the stem. Cortex with hollow root } \\
\text { hypodermis. Brown elliptical lesions at sites of lateral root } \\
\text { emergence. Crown exhibits dry-brown rot }\end{array}$ \\
\hline 13 & f. sp. batatas & Sweet potato & $\begin{array}{l}\text { Yellowing of older leaves, transient wilting of vines, stem rot, } \\
\text { brown vascular discoloration. Infected sprouts wilt }\end{array}$ \\
\hline 14 & f. sp. betae & Sugar beet & $\begin{array}{l}\text { Stunted plants, wilted leaves, chlorotic leaves with necrosis at the } \\
\text { edges, dried tap root brown to black in color, and plant death }\end{array}$ \\
\hline 15 & f. sp. cyclaminis & Cyclamen & $\begin{array}{l}\text { Yellowing of leaves on young plants. Wilting and withering of } \\
\text { leaves and flowers on mature (flowering) plants. Brown to } \\
\text { brownish-black vascular discoloration of roots and tubers. } \\
\text { Decaying of older roots and plant death }\end{array}$ \\
\hline 16 & f. sp. herbemontis & Grapes & $\begin{array}{l}\text { Plant wilting and death, root decay with brown vascular } \\
\text { discoloration, pink discoloration in the cortical and vascular } \\
\text { tissues, tyloses in the xylem, and rotting of epidermal tissues of } \\
\text { the roots. Yellow spots which expand into streaks before leaves die } \\
\text { and drop, delayed and weak shoot growth, and low fruit yields }\end{array}$ \\
\hline 17 & f. sp. dianthi & Carnation & $\begin{array}{l}\text { Chlorotic roots and crook neck shoots, leaves and stem wither } \\
\text { and turn brown. Brown vascular discoloration that extends into } \\
\text { cortex and pith. Shredding of internal tissues }\end{array}$ \\
\hline 18 & f. sp. lactucae & Lettuce & $\begin{array}{l}\text { Stunted and chlorotic plants. Death of older leaves and collapse } \\
\text { of the entire plant. Taproot turns pink to red in the vascular } \\
\text { tissue. Discoloration often extends into the cortex and may be } \\
\text { accompanied by extensive rotting }\end{array}$ \\
\hline 19 & f. sp. gladioli & Gladiolus & $\begin{array}{l}\text { Dry corm rot, brownish to black in color. Yellowing and } \\
\text { browning of leaves. Premature leaf death }\end{array}$ \\
\hline 20 & f. sp. nicotianae & Tobacco & $\begin{array}{l}\text { Sudden wilting of one or more leaves on the plant accompanied } \\
\text { by yellowing and finally browning and death, wilting, brown } \\
\text { vascular discoloration, dry vascular rot, and brittle and } \\
\text { achlorophytic leaves }\end{array}$ \\
\hline
\end{tabular}

Henrique et al. 2015

Can et al. 2004

Li et al. 2012

Reyes and Chadha 1972

Ibtissem et al. 2014

Gupta et al. 2013

Rabiei-Motlagh et al. 2010

McCain and Noviello 1985

Wang and McKie 2007

Grogan and Kimble 1959

Hedge et al. 2012

Cramer et al. 2003

Pataky 1988

Dore 2009

Pennypacker and Nelson 1972

Scott et al. 2010

Pataky 1988

Johnson 1921

(Continued on next page) 
and Prasad 2013). These PRR activate the plant's basal immune response by transcribing pathogenesis-related $(P R)$ genes and triggering the production of reactive oxygen species (ROS) and other defense metabolites. Release of nonspecific exogenous and endogenous elicitors such as oligomeric or monomeric fragments of both the cuticle and the cell wall elicit innate defense responses and form the first line of defense against $F$. oxysporum (Hückelhoven 2007). Ingress of $F$. oxysporum disrupts pectin layers and results in release of galacturonic acid-containing fragments. These fragments act as signaling substances that mediate defense response and impart resistance by strengthening defensive barriers (Benhamou et al. 1990). Chitin elicitorbinding protein (CEBiP) and the chitin elicitor receptor kinase (CERK1) are the components of the defense signaling pathway that recognize chitin oligosaccharides, and genes encoding these proteins are upregulated in resistant crop

Table 1. (Continued from previous page)

\begin{tabular}{|c|c|c|c|c|}
\hline Number & F. oxysporum & Crop infected & Symptoms & Reference \\
\hline 21 & f. sp. narcissi & Narcissus & $\begin{array}{l}\text { Stunted, distorted, and yellow shoots. Shoots die prematurely. } \\
\text { Stunted roots. Decayed basal plate of bulb with a dry and } \\
\text { spongy, chocolate-brown to purplish-brown rot. Decayed bulb } \\
\text { with white or pinkish white mold between the scales }\end{array}$ & Pataky 1988 \\
\hline 22 & f. sp. medicaginis & Alfalfa & $\begin{array}{l}\text { Brown cankerous depressions at the bases of lateral roots, root } \\
\text { rot, bright yellow upper leaves which fade to light buff color of } \\
\text { dead and bleached alfalfa straw. Basal leaves may have a tinge } \\
\text { of old rose or some shade of pink. Tips of the stem droop and } \\
\text { wilt, stunting, and plant death }\end{array}$ & Weimer 1928 \\
\hline 23 & f. sp. lini & Flax & $\begin{array}{l}\text { Collapsing of young seedlings. Rolling and withering of } \\
\text { cotyledons, dark green to brown patches appear on leaves } \\
\text { followed by shriveling, dropping off, and drying of leaves. } \\
\text { Discoloration of the vascular tissues }\end{array}$ & Kumar et al. 2014 \\
\hline 24 & f. sp. lentis & Lentil & $\begin{array}{l}\text { Severe grain losses, seedling wilt, or adult plant wilt during } \\
\text { reproductive growth }\end{array}$ & Stoilova and Chavdarov 2006 \\
\hline 25 & f. sp. niveum & Watermelon & $\begin{array}{l}\text { Vascular browning of seedlings, wilting of leaflets, and death of } \\
\text { seedling. Wilting and death of plant }\end{array}$ & Dau et al. 2009 \\
\hline 26 & f. sp. palmarum & Palm & $\begin{array}{l}\text { Initially one-sided chlorosis or necrosis of older leaf blades } \\
\text { occurs. Reddish-brown stripe appears along the petiole and } \\
\text { rachis. Discoloration of internal tissue. Later, entire canopy } \\
\text { becomes desiccated and necrotic. Leaves do not droop or hang } \\
\text { down around the trunk }\end{array}$ & Elliott et al. 2010 \\
\hline 27 & f. sp. pisi & Pea & $\begin{array}{l}\text { Pale foliage, downward curling of leaves, and vascular } \\
\text { discoloration both below- and aboveground. Above- and } \\
\text { belowground vascular system turns light yellow to brick-red } \\
\text { color and the lower subterranean portion of the stem becomes } \\
\text { larger than normal }\end{array}$ & Kraft et al. 2000 \\
\hline 28 & f. sp. passiflorae & Passion fruit & $\begin{array}{l}\text { Pale-green leaves exhibiting dieback. Dropping of lower leaves } \\
\text { and plant death in young plants. Yellowing of leaves and plant } \\
\text { wilt and death in adult plants. Vascular discoloration at root, } \\
\text { collar, twig, and stem. Lesions and fissures in collar and stem } \\
\text { at high humidity }\end{array}$ & Joy and Sherin 2012 \\
\hline 29 & f. sp. perniciosum & Mimosa trees & $\begin{array}{l}\text { Linear bark fissures, vascular discoloration, blocked vessels, } \\
\text { and lenticular swelling and defoliation }\end{array}$ & Stipes and Phipps 1975 \\
\hline 30 & f. sp. ricini & Castor & $\begin{array}{l}\text { Gradual yellowing, interveinal necrosis, hang down of leaves, } \\
\text { and blackening and necrosis of roots predominantly expressed } \\
\text { at flowering and spike formation. Discoloration of young } \\
\text { seedlings, black lesions above collar regions in stem, leaves } \\
\text { with petiole dry up and hang down. Yellowing, shriveling with } \\
\text { marginal and interveinal necrosis of leaves }\end{array}$ & Dange et al. 2006 \\
\hline 31 & f. sp. strigae & Striga & $\begin{array}{l}\text { Wilting, dieback, necrosis, and chlorosis, browning of the tips of } \\
\text { some leaves, and browning of shoots }\end{array}$ & Endah 2011 \\
\hline 32 & f. sp. tuberosi & Potato & Dry rot, chlorosis, and wilting & Remadi et al. 2009 \\
\hline 33 & f. sp. tulipae & Tulip & $\begin{array}{l}\text { Leaves turn red, wilt, and die prematurely. Diseased bulbs are } \\
\text { dull gray to chalky white in color, have a shrunken basal rot, } \\
\text { and fail to sprout. Fewer roots appear on corms }\end{array}$ & Pataky 1988 \\
\hline 34 & f. sp. vasinfectum & Cotton & $\begin{array}{l}\text { Cotyledon drop, leaf chlorosis and necrosis, plant wilt and } \\
\text { death. On older plants, veins are darkened, leaves became } \\
\text { partly chlorotic and sometimes abscised. Vascular } \\
\text { discoloration usually occurs in the tap root and in the lower } \\
\text { part of the stem }\end{array}$ & Kim 2005 \\
\hline 35 & f. sp. raphanin & Radish & $\begin{array}{l}\text { Yellowing of a single leaf, dark vascular discoloration, root rot, } \\
\text { general wilting and dieback of plants }\end{array}$ & du Toit and Pelter 2003 \\
\hline 36 & f. sp. fragariae & Strawberry & $\begin{array}{l}\text { Reddish-brown discoloration on the crown, drying and early } \\
\text { senescence of mature leaves, followed by stunting and wilting } \\
\text { of entire plant }\end{array}$ & Garrido et al. 2016 \\
\hline 37 & F. oxysporum & Saffron & $\begin{array}{l}\text { Infected corms possess dark-brown, sunken, and irregular } \\
\text { patches below the corm scales, mostly near root and bud } \\
\text { regions. In severe cases, the entire corm turns into a black } \\
\text { powdery mass }\end{array}$ & Husaini 2014 \\
\hline
\end{tabular}


varieties ( $\mathrm{Li}$ et al. 2012). The phenolic pathway is activated, too, as a part of defense response against cell-wall-derived elicitors from pathogens. Oligosaccharide derivatives of $F$. oxysporum ( $\alpha$-D-mannopyranosyl-[1-2]- $\alpha / \beta$-D-glucopyranosyl and $\alpha-D$ mannopyranosyl inositol) induce phenylalanine ammonia lyase activity (Nita-Lazar et al. 2004). Several defense genes such as thionins like Thi2.1 (small, basic, cysteine-rich antimicrobial proteins), $P R-1$ and $P R-5$ genes, as well as the plant defensin gene $P d f 1.2$ are induced in Arabidopsis plants following infection by $F$. oxysporum (Epple et al. 1997).

\section{HOST PERCEPTION AND VIRULENCE}

Perception of the host is a prerequisite for vascular infection by F. oxysporum. The pathogen recognizes suitable hosts, and penetrates and invades plant tissues (Michielse et al. 2009). It successfully circumvents plant nonself-recognition and basal defense during penetration. Dihydroxy-C16 and trihydroxy-C18 acids, characteristic hydroxy acids unique to cutin, act as specific inducers, giving the fungus a failsafe method of sensing that it is in contact with the plant (Woloshuk and Kolattukudy 1986). Fusarium spp. perceive chemical and physical signals from the host and respond with the appropriate metabolic and morphogenetic changes required for pathogenic development. Also, host-derived hydrolases, including chitinases and glucanases, release monomers that act as elicitors, conveying a signal to the fungus for the synthesis of enzymes (cutinases, pectinases, endopolygalacturonases, and other hydrolytic enzymes) required for host penetration (Woloshuk and Kolattukudy 1986).

Different signaling cascades are activated in Fusarium spp. during host infection. Their activation mainly depends on the perception of signals by different receptor proteins, usually at the cell surface, which bind the signal molecule. Membrane proteins Msb2 and Sho1 regulate the infection processes in F. oxysporum (Fig. 1A). Msb2, a highly glycosylated transmembrane protein, and Sho1, a tetraspan transmembrane protein, contribute to plant infection by regulating the Fmk1 pathway. Required for full phosphorylation of Fmk1, Msb2 and Sho1 together function upstream of Fmk1. Msb2 and Sho1 contribute to virulence in several ways: they (i) upregulate Fmk1regulated genes encoding different enzymes involved in cell wall biogenesis, (ii) contribute to cell wall stress response, and (iii) promote Fmk1-dependent virulence functions. Together with Fmk1, these membrane proteins (Sho1 and Msb2) are required for upregulation of $c h s V, f k s 1$, and gas 1 genes involved in cell wall biogenesis (Pérez-Nadales and Di Petro 2011, 2015).

RHO-type GTPase Rhol of Fusarium spp. is required for the correct assembly of the cell wall and for virulence (Fig. 1A). Rho1 positively regulates posttranslational activity of glucan synthase and plays an important role in maintaining the hyphal architecture, which prevents its detection by the host (Martínez-Rocha et al. 2008). GTP-binding proteins are essential components that mediate cellular responses to environmental stimuli. When an extracellular signal molecule binds to a $\mathrm{G}$ protein coupled receptor, the receptor undergoes a conformational change that enables it to activate a trimeric GTP-binding protein ( $\mathrm{G}$ protein). The $\mathrm{G}$ protein is attached to the cytoplasmic face of the plasma membrane, and is composed of three protein subunits: $\alpha, \beta$,

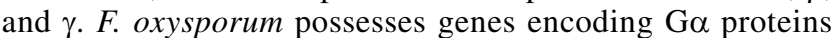
FGA1 and FGA2 and G $\beta$ protein FGB1. FGA1 and FGA2 regulate adenyl cyclase activity and alter cAMP levels, which result in pathogenicity (Jain et al. 2002, 2003, 2005) (Fig. 1F). Disruption of FGA1 and FGA2 leads to reduced pathogenicity and alterations in colony morphology.

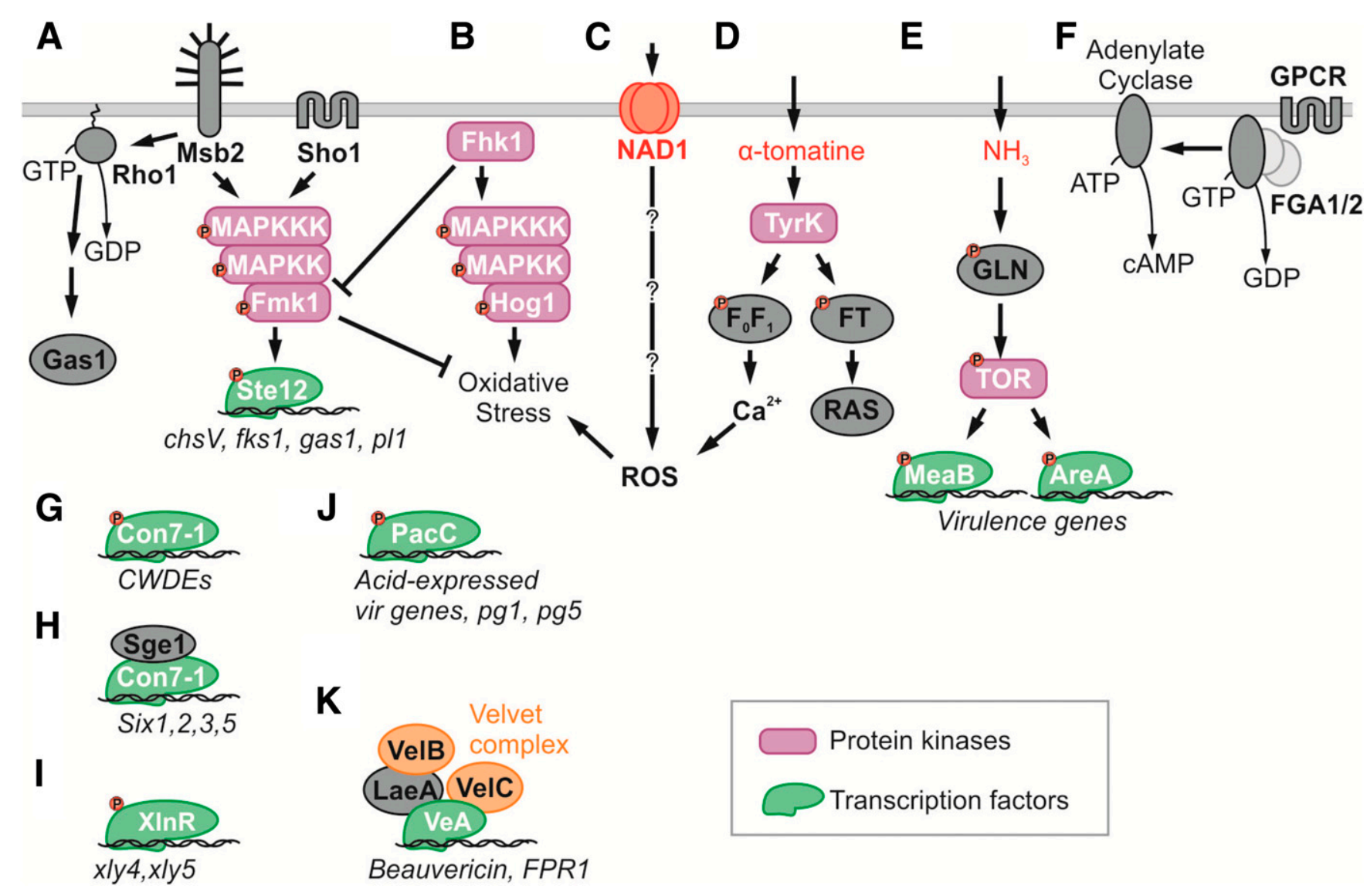

Fig. 1. Pictorial representation of the major players in the Fusarium oxysporum infection process. 


\section{SIGNALING IN THE PATHOGEN}

Stimulation by a signal initiates a specific signal transduction pathway. The three-component MAP kinase module processes the signals inside the receiving cell and distributes it to the appropriate intracellular targets (Fig. 1A and B). The first module of this cascade, MAP kinase kinase kinase, phosphorylates and, thereby, activates MAP kinase kinase which, in turn, phosphorylates and activates MAP kinases (MPK). Once activated, the MPK relay the signal downstream by phosphorylating various proteins in the cell, including gene regulatory proteins and other protein kinases (Widmann et al. 1999).

MPK play a fundamental role in determining virulence of F. oxysporum. These MPK channel information required for imparting full virulence. There are various MPK that regulate virulence in $F$. oxysporum, some of which have been studied in detail while some are yet to be studied. MPK Fmk1, belonging to the yeast and fungal extracellular signal-regulated kinase (YERK1) subfamily, is indispensable for virulence of $F$. oxysporum. Fmk1 is an important component of the signal transduction pathway that regulates various infection processes of $F$. oxysporum such as adhesion of $F$. oxysporum to roots of host formation of infection hyphae, root attachment and penetration, vascular colonization, and invasive growth on the living plant tissue. Fmk1 also plays an important role in maceration of the fruit tissue in tomato fruit and production of aerial mycelium on its surface (Di Pietro et al. 2001). Fmk1 regulates expression of several genes such as endo-pectate lyase $p l 1, c h s V, f k s 1$, and gas 1 . The reduced expression of these genes in fmkl mutants explains the inability of $F$. oxysporum to cause pathogenicity (Nadalez and Di Pietro 2014).

Histidine kinase Fhk1 is another key element that contributes to virulence, oxidative stress, and fungicide sensitivity by recruiting several signaling pathways. Fhk1 regulates postpenetration events and enhances disease symptoms (Rispail and Di Pietro 2010). Fhk1 controls stress adaptation, partly by recruiting an MPK Hog 1 and partly by inhibiting Fmk1 that acts as a negative regulator of oxidative stress response. Activation of Fhk1 is followed by recruitment of the Hog 1 pathway in $F$. oxysporum (Fig. 1B).

\section{F. OXYSPORUM VIRULENCE}

\section{Genetic regulation.}

Genetic regulation of virulence in $F$. oxysporum is quite complex, with a number of genes regulating virulence. $F$. oxysporum f. sp. lycopersici strain 4287 genome size is $61 \mathrm{Mb}$ and comprises 17,735 genes distributed over 15 chromosomes (Ma et al. 2013). The genome is compartmentalized into two regions: the core genome responsible for primary metabolism and reproduction and the adaptive genome responsible for pathogen virulence (Ma et al. 2013). Genes involved in virulence and host specialization are located on pathogenicity chromosomes (Ma et al. 2013). Genome comparison of pathogenic $F$. oxysporum formae speciales virulent on tomato reveal horizontal acquisition of LS genomic regions within them. These LS regions include four entire chromosomes (chromosomes 3, 6, 14, and 15) and parts of chromosome 1 and 2 (Ma et al. 2010; Niño-Sánchez et al. 2016). These regions possess a surprising enrichment of transposable elements as well as SIX genes (Houterman et al. 2008; Rep et al. 2004). Colonization of the tomato xylem system is associated with the secretion of SIX proteins. Genes for Six1 (avr3), Six3 (avr2), Six5, Six6, and Six7 as well as a gene encoding the in planta secreted oxidoreductase (ORX1) are all located on chromosome 14. This chromosome is present in all pathogens causing tomato wilt but absent in avirulent strains, suggesting its horizontal acquisition
(Ma et al. 2010). The mobilization of these LS chromosomes by avirulent Fusarium spp. may lead to rapid emergence of new pathogenic lineages (Ma et al. 2010).

Recently, 61 complete mitogenomes of $F$. oxysporum species complex strains were de novo assembled and annotated, which resolved them into three phylogenetic species (Brankovics et al. 2017). Comparative analysis revealed that recombination takes place within the phylogenetic species, indicating presence of a parasexual cycle in $F$. oxysporum.

The FRPl gene, encoding a protein with a conserved F-box motif, plays an important role during the first phase of infection. In addition, the fungal genes $A R G 1$ (encoding arginine-succinatelyase) (Namiki et al. 2001), Fow1 (encoding a mitochondrial carrier protein) (Inoue et al. 2002), Fow2 (encoding a $\mathrm{Zn}[\mathrm{II}] 2 \mathrm{Cys} 6$ transcription regulator), and SNF1 (sucrose nonfermenting) collectively contribute to pathogenicity. Furthermore, the $\mathrm{Clcl}$ gene (encoding a chloride channel) regulates laccase activity and virulence in F. oxysporum (Canero and Roncero 2008). Members of Velvet complex VeA, VelB, and VelC positively regulate developmental processes such as hyphal growth, asexual sporulation, and conidial growth. The Velvet complex remodels chromatin and promotes its accessibility at target loci, facilitating expression of the biosynthetic gene cluster for beauvericin (Fig. 1K). The exact mechanism of chromatin remodeling remains to be elucidated (López-Berges et al. 2013).

The presence of an intact fungal cell wall is essential for fungal pathogenicity. The genes that confer this pathogenicity trait in $F$. oxysporum are those encoding chitin synthase V, mannose-6-phosphate isomerase, and DCW1 (Michielse et al. 2009). Peroxin genes PEX1, PEX10, PEX12, and PEX26 encoding four peroxins involved in docking and translocation of receptor-cargo moieties across the peroxisomal membrane also contribute to pathogenicity (Michielse et al. 2009). Largescale insertional mutagenesis of $F$. oxysporum genome carried out by Michielse et al. (2009) revealed that a number of pathogenicity genes influence successful colonization of plant tissues such as chitin synthase $\mathrm{V}(c h s V)$, vitamin $\mathrm{B} 6$ metabolism protein (FOXG_08652), a GTPase-activating protein (FOXG_07699), an RNA polymerase II transcription mediator (FOXG_08531), and a $\mathrm{Ca}^{2+}$ permease/membrane transporter involved in calcium homeostasis $\left(F O X G_{-}\right.$11097). In addition, the results of insertional mutagenesis reveal that genes encoding components of amino acid and lipid metabolic pathways, cell wall integrity, protein translocation, and degradation may have a function in vegetative growth and, thus, influence the pathogenicity of $F$. oxysporum, too. Some of these genes are present as multiple copies in the genome of $F$. oxysporum (i.e., chitin synthase V, developmental regulator FlbA, carboxy-cis,cis,muconate cyclase, and transcription factor Fow2).

\section{Transcriptional regulation.}

Virulence in $F$. oxysporum is a polygenic trait that is governed by transcriptional regulation of many genes and the transcriptional factors regulating their expression. Each of these genes contributes to virulence and, collectively, they govern the virulence of $F$. oxysporum. These genes encode various components of different pathways that sense the host plant and encode products that play important roles in virulence. The expression of these genes is regulated by a complex array of transcriptional factors. There are seven transcriptional regulators described for virulence in $F$. oxysporum, as follows. (i) Con7-1 is an important transcription factor that regulates vital processes of morphogenesis in F. oxysporum-like cell-wall biogenesis, cell division, and differentiation of infectious structures. Con7-1 possess a nuclear localization signal, a $\mathrm{Cys}_{2} \mathrm{His}_{2}$ DNA-binding domain, a coiled-coil region responsible for 
protein-protein interactions, and a proline/glutamine-rich $\mathrm{C}$ terminal transactivation domain. Con $7-1$ regulates expression of several genes encoding proteins such as endopolygalacturonases, cellulases, and Six proteins (Ruiz-Roldan et al. 2015) (Fig. 1G and H). (ii) Sgel regulates the expression of $S I X$ genes and is required for colonization of the xylem system and disease development (Michielse et al. 2009). Sgel expression, in turn, is regulated by $F T F 1$ and $F T F 2$ transcription factors (NiñoSánchez et al. 2016). (Fig. 1H). (iii) Ftfl encodes yet another important transcription factor that positively regulates virulence during early stages of infection (Ramos et al. 2007; van der Does 2016). (iv) Ste 12 encodes a homeodomain transcription factor that regulates invasive growth downstream of the Fmk1 pathway (Rispail and Di Pietro 2009). (v) $X \ln R$ encodes a major transcriptional activator of xylanase genes $x l y 3, x l y 4$, and xyl5 regulating the expression of these plant cell-walldegrading enzymes (Calero-Nieto et al. 2007) (Fig. 1I). (vi) Transcriptional factor encoding genes $c t f l$ and $c t f 2$ regulate the expression of genes encoding cutinases and lipases (Bravo-Ruiz et al. 2013). (vii) Finally, pacC encodes a transcription factor that acts as a negative regulator of virulence by repressing expression of acid-expressed virulence genes and polygalacturonases $\mathrm{pg} 1$ and pg5 (Caracuel et al. 2003) by binding the consensus sequence 5'-GCCAAG-3' (Fig. 1J).

\section{Nitrogen sources and virulence.}

Nitrogen-containing metabolites are a key signal that regulates expression of virulence genes in $F$. oxysporum. Preferred nitrogen sources are readily assimilated compounds such as ammonium or glutamine. Their presence causes nitrogen catabolite repression, whereby genes required for exogenous nitrogen source utilization are downregulated (Marzluf 1997; Wong et al. 2008). As such, infection-related functions (cellophane invasion), vegetative hyphal fusion, and root adhesion are repressed (in $F$. oxysporum). Transmission of the repressing signal requires conserved Ser/Thr kinase TOR and the bZIP transcriptional regulator $\mathrm{MeaB}$ (Fig. 1E). Glutamine synthase phosphorylates TOR. TOR transmits its signal to MeaB and negatively regulates transcription of virulence genes. AreA, belonging to the GATA binding family of transcription factors, acts as an activator of nitrogen catabolic genes whereas MeaB mediates repression of nitrogen catabolic genes but both regulators act as repressor of virulence functions. MeaB and AreA repress expression of the Ste12 transcriptional regulator of the Fmk1 pathway (López-Berges et al. 2010). The nitrogen response pathway and Fmk1 pathway are antagonistic in action. The Fmk1 pathway positively regulates expression of virulence genes whereas the preferred nitrogen source represses virulence genes.

\section{HOST RESISTANCE}

\section{Transcription factors.}

Transcription factors in the host play an important role as positive and negative regulators of antimicrobial compounds during $F$. oxysporum infection. One among these is ATAF2, which belongs to the NAC protein family and increases susceptibility to $F$. oxysporum. Its overexpression in Arabidopsis reduces resistance to $F$. oxysporum. It functions as a repressor of Fox-inducible defense response in Arabidopsis. ATAF2 expression responds to jasmonic acid (JA) and salicylic acid (SA) treatment and its gene product blocks the expression of Fox-inducible defense genes plant defensin1.2 (PDF1.2) and PR1 (Berrocal-Lobo and Molina 2008). Similarly, overexpression of transcription factors ERF4 and WRKY7O also leads to decreased resistance against $F$. oxysporum (BerrocalLobo and Molina 2008). In contrast, overexpression of ERF1,
$E R F 2$, and $E R F 14$, which encode proteins belonging to the APETALA/ethylene (ET)-responsive-element binding protein (EREBP) family, imparts resistance against $F$. oxysporum. Induction of ERF1 and ERF2 depends on ERF14. These transcription factors are involved in ET and JA signaling. ERF72, another transcription factor belonging to the AP2/ERF family, suppresses programmed cell death and regulates expression of PDF1.2 and GST6 (Ogawa et al. 2005). There are some transcription factors whose role remains to be elucidated. $M Y B 122$; ANACO3 and -42; AtbHLHO38 and -039; and WRKY45, -51, -53, -63 , and -75 are all induced at early and late stages of $F$. oxysporum infection. $M Y B 15$ and -51 are induced at an early stage only, whereas ERF1 and ANACO19 are uniquely induced at late infection stages (Zhu et al. 2013). MYB51 has a role in regulating biosynthesis of antimicrobial substances, while ANACO19 regulates JA-signaled defense response downstream of $M Y C 2(\mathrm{Bu}$ et al. 2008).

\section{Genes.}

Several genes responsive to $F$. oxysporum infection have been identified thus far. These include genes involved in biosynthesis of JA, indole glucosinolate, camalexin, and callose (Bednarek et al. 2009; Clay et al. 2009; Kidd et al. 2011; Liu et al. 2010; Manzo et al. 2016; Pfalz et al. 2009; Zhu et al. 2013). Also responsive to $F$. oxysporum infection are genes encoding dirigent-like protein (At1g64160), germin-like protein (At1g18970), CAP family protein (cysteine-rich secretory proteins, antigen 5, and PR1) (At4g33720), and wound-responsive family proteins (At4g10270 and At4g33560). The genes which are significantly upregulated in F. oxysporum-infected Arabidopsis plants include those involved in the biosynthesis pathways of tryptophan, indole-3-methyl-glucosinolate, and camalexin (Kidd et al. 2011).

The role of resistance $(R)$ genes conferring $F$. oxysporum immunity is quite significant. These genes confer resistance against F. oxysporum that express the corresponding avirulence $(A v r)$ gene. Dominant plant $R$ genes against different races of $F$. oxysporum have been identified in several crops (Dean et al. 2012). Interaction between $F$. oxysporum sp. lycopersici and tomato is race or cultivar specific. Immunity to F. oxysporum sp. lycopersici was first found in Missouri accession 160 (Lycopersicon pimpinellifolium PI79532) and the symbol $I$ was used to denote the factor (gene) of immunity (Huang and Lindhout 1997). There are three races of this pathogen (races 1,2 , and 3 ), of which race 3 is the most devastating. Corresponding to these races, three loci $(I-1, I-2$, and $I-3)$ which confer resistance in tomato were identified earlier (Panthee and Chen 2010). All commercially cultivated tomato lines (L. esculentum) lacking $I$ genes are susceptible to $F$. oxysporum sp. lycopersici. The literature is confusing with regard to the use of the gene symbol $I$ and $I-I$ for race 1 resistance. At present, most researchers use $I$ when the resistance in L. pimpinellifolium is concerned and $I-I$ when the resistance is derived from other sources such as L. pennellii (Huang and Lindhout 1997). $R$ genes against $F$. oxysporum sp. lycopersici have been characterized and mapped to three clusters on chromosome 7, 8, and 11 of tomato (Gonzalez-Cendales et al. 2016). $I$ and $I$-2 have been mapped on chromosome 11 (Laterrot 1976; Paddock 1950), I-1 and I-3 on chromosome 7 (Bournival et al. 1989; Hemming et al. 2004; Sarfatti et al. 1991), and I-7 on chromosome 8 (Gonzalez-Cendales et al. 2016). Actually, I-3 and I-7 genes for resistance to $F$. oxysporum sp. lycopersici race 3 were identified in L. pennellii from accessions LA716 (Scott and Jones 1989) and PI414773 (McGrath et al. 1987) but both genes were designated I-3. However, gene mapping revealed that the two genes were not the same ( $\mathrm{Lim}$ et al. 2006). The $I-3$ gene from LA716 encodes an S-receptor-like kinase (SRLK) protein 
(Catanzariti et al. 2015; Lim et al. 2008), while I-7 encodes a leucine-rich repeat (LRR) receptor-like protein and, unlike $I-3$ (and I-2)-mediated resistance, it is not suppressed by Avrl (Gonzalez-Cendales et al. 2016). Using transgenic tomato plants carrying only the $I-7$ gene for $F$. oxysporum sp. lycopersici resistance, Gonzalez-Cendales et al. (2016) found that $I-7$ also confers resistance to F. oxysporum sp. lycopersici races 1 and 2 . A submember of the $I-2$ locus $(I-2 C-5)$, belonging to the nucleotidebinding site (NBS)-LRR family of resistance genes, has also been shown to confer partial resistance in transgenic plants (SelaBuurlage et al. 2001). The $R$ gene $I-3$ confers recognition of the $S I X 1$ gene product of $F$. oxysporum, which encodes a cysteine-rich protein (Rep et al. 2004). Six-I loci (I for "immunity to Fusarium wilt") confer partial resistance to different $F$. oxysporum sp. lycopersici races and the locus I-2 confers complete plant resistance to specific races of Fox. Some genes of SIX-I loci encode resistance proteins of the NBS-LRR subclass (Berrocal-Lobo and Molina 2008), today called nod-like receptors (NLR). In Arabidopsis, several NLR-encoding genes (At1g57630, At3g04220, and At4g11170) of the Toll interleukin-1 receptor class are also induced following $F$. oxysporum infection (Zhu et al. 2013).

Several receptor-like kinases (RLK) are also implicated in F. oxysporum resistance. Arabidopsis has six dominant resistance loci to F. oxysporum. Among them, RFO1 is the largest contributor to resistance and offers resistance toward three $F$. oxysporum species. RFO1/WAKL-22 encodes a wall-associated RLK (WAK) and confers broad resistance interdependent on RFO2, RFO4, and RFO6 (Diener and Ausubel 2005). Some RLK genes (At3g59700, At5g01540, At5g60900, At1g65790, At4g13920, WAK1, WAK3, and WAKL10) are also induced upon $F$. oxysporum infection in Arabidopsis. It seems that plants may use these receptors to detect multiple elicitors released by F. oxysporum (Zhu et al. 2013).

\section{Defense molecules and hypersensitive response.}

Plants are equipped with defense molecules against $F$. oxysporum. These defense molecules can kill their target pathogen through their precise defense signaling approaches. $\alpha$-Tomatine, a glycoside lycotetraose, is a major saponin in tomato that has fungicidal action on certain strains of $F$. oxysporum. Elucidation of the mode of action of $\alpha$-Tomatine reveals that it induces cell death by activating a Tyr kinase and its downstream targets, a farnesyl transferase and the mitochondrial ATP synthase $\mathrm{F}_{0} \mathrm{~F}_{1}$ ATP, leading to intracellular $\mathrm{Ca}^{2+}$ elevation and the oxidative burst. Cross talk between Tyr phosphorylation and Ras pathways also takes place (Fig. 1D) (Ito et al. 2007). NAD1, an antifungal plant defensin, kills $F$. oxysporum by binding to the cell wall of hyphae, followed by permeabilization of the fungal plasma membrane via the formation of an aperture and induction of ROS production via unknown pathways, ultimately causing cell death (Fig. 1C) (van der Weerden et al. 2008).

The second layer of defense is the hypersensitive response (HR), which is characterized by the accumulation of ROS during the oxidative burst, and the accumulation of antimicrobial proteins and phytoalexins. These immune responses culminate in a local, cellular suicide associated with restricting the spread of pathogens. ROS are induced by either cell wall peroxidases or plasma membrane NADPH oxidases. Peroxidase-dependent ROS production has been observed in Arabidopsis cell suspension cultures in response to $F$. oxysporum elicitors (Davies et al. 2006). F. oxysporum-derived elicitor necrosis and ETinduced peptide 1 (Nep1) generates NADPH oxidase-dependent ROS. Expression of genes encoding NADPH oxidases such as $A t R B O H-A,-B$, and $-D$ are significantly upregulated upon exposure to Nep1 (Bae et al. 2006; Zhu et al. 2013). NADPH oxidases are also upregulated in cotton, wheat, banana, and cucumber after infection by F. oxysporum (Dowd et al. 2004; Li et al. 2012). However, how these oxidases impart basal resistance or are involved in the HR to $F$. oxysporum remains unclear.

Another defense system that operates in plants is systemic acquired resistance, which is activated by hormones, mostly SA (Chen et al. 2014). It has been proposed that resistance to $F$. oxysporum is mediated mainly by JA and ET signaling pathways (Li et al. 2012). Genes responsive to ET stimulus are activated early during infection. High transcriptional levels of genes encoding ET-insensitive 3 and ET-insensitive 3-like 1 were observed in a resistant variety of banana during early stages of $F$. oxysporum challenge. In contrast, genes involved in JA metabolism and signaling, as well as genes responsive to SA and abscisic acid, are activated later. Levels of core JAsignaling component jasmonate ZIM motif proteins, TIFY10Blike gene, and a jasmonate-inducible protein (the extracellular superoxide dismutase $[\mathrm{Cu}-\mathrm{Zn}]^{2+}$ ), were found to be high in roots of the resistant banana variety, supporting the notion that JA plays a positive role in imparting resistance to $F$. oxysporum. The high expression levels of genes encoding lipoxygenase-like and allene oxide synthase also suggest that JA levels are quite high in resistant varieties ( $\mathrm{Li}$ et al. 2012; Zhu et al. 2013). Despite the fact that levels of JA are high in resistant varieties, a role of JA is somewhat controversial. Some studies reported that the JA coreceptor COI1 and JA-associated gene expression pathways involving $M Y C 2$ and PFT1 impart susceptibility to F. oxysporum (Anderson et al. 2004; Kidd et al. 2009; Thatcher et al. 2009). Other studies indicated that $F$. oxysporum manipulates the JA signaling pathway for disease progression. Indeed, JA signaling components predispose plants to $F$. oxysporum as well as suppress MAMP responses (Chen et al. 2014). Detailed studies that elucidate the exact role of these hormones in disease resistance remain to be carried out.

\section{Noncoding RNA.}

Noncoding RNA (ncRNA) play an important role in a wide range of biological processes, including response to biotic or abiotic stresses. They are categorized as short ncRNA $(<200 \mathrm{bp})$ and long ncRNA (lncRNA; >200 bp) based on their lengths. Thus far, 15 long noncoding natural antisense transcripts (lncNAT) and long intergenic ncRNA (lincRNA) and 20 novel intergenic transcriptionally active regions responsive to $F$. oxysporum infection have been identified in Arabidopsis. Of these, five lincRNA play important roles in defense against $F$. oxysporum infection (Zhu et al. 2014). The most significantly induced lncNAT is Atlg13609, while F. oxysporum-induced antisense transcription was also seen for At $1 g 13607$ and At $\lg 13608$. These three genes are clustered together in a $2.5-\mathrm{kb}$ region on chromosome 1 , and belong to a small clade of the defensin-like protein family (Silverstein et al. 2005).

F. oxysporum infection leads to change in miRNA levels. Ten microRNA (miRNA), belonging to eight families, are upor downregulated at different time points following Fusarium infection of Arabidopsis. miRNA miR159b slightly induces expression levels of its target genes MYB33 and MYB65. Similarly, the enhanced expression of MIR398b and MIR398c during late stages downregulates their target genes, particularly the gene encoding copper superoxide dismutase2 (CSD2), suggesting the possible role of miR398-mediated regulation of $C S D$ genes in a defense network against $F$. oxysporum infection (Zhu et al. 2013).

\section{SUMMARY}

The emergence of $F$. oxysporum as a deadly vascular wilt fungus can be attributed to the collective contribution of individual genes which encode different receptors that sense 
the host, MAP and His kinases that relay the message onward, transcriptional regulators of genes encoding virulence products, and pathogenesis genes. Extensive research has been conducted to elucidate the complexity of the signaling pathways and transcriptional regulation of virulence genes involved in pathogenicity of $F$. oxysporum. However, there are loopholes and gaps in the complete picture. Proteomic studies can help fill these loopholes and gaps. Expressional proteomics can significantly contribute to the analysis of global changes in protein expression of resistant and susceptible cultivars under $F$. oxysporum attack. In addition, it can also analyze the proteome of pathogenic and nonpathogenic races of F. oxysporum when they attack the same host. Different posttranslational modifications related to alterations in the "host proteomic profile" in response to Fusarium infection can also be elucidated. The chemical proteomic based novel technique activity-based protein profiling can help reveal the role of "active" proteins involved in such interactions. There are probes available for different classes of active proteins such as serine hydrolases, cysteine proteases, glucosidases, and so on. Experiments involving such fluorescent probes display remarkably different profiles upon $F$. oxysporum infection in saffron. Activities of putative $\alpha$-glucosidase $(100 \mathrm{kDa})$ and putative $\beta$-glucosidases ( 50 to $70 \mathrm{kDa}$ ) are increased, whereas the activity of one strong $50-\mathrm{kDa}$ and several $60-\mathrm{kDa}$ weaker serine hydrolase signals is reduced upon infection. The activity profile of cysteine proteases representing papain-like cysteine proteases or vacuolar processing enzymes changes dramatically, too (Husaini et al. 2018). Metabolomic profiling of the fungus can further narrow the gap of understanding as the fine tuning of different networks that render $F$. oxysporum deadly finally culminate into metabolic products.

Exploitation of this repertoire of knowledge can assist us in development of crop varieties that can resist fungal attack by approaches like RNAi to silence essential genes such as the ones that prevent detection of the fungus by cognate receptors of the host or disruption of receptors which lead to reduced pathogenicity. We could also explore the possibilities of multiplex genome editing of $F$. oxysporum with CRISPR/Cas9. Transgenic plants expressing the cas 9 protein and multiple sgRNA targeting genes vital for $F$. oxysporum pathogenesis can be generated, and this could successfully circumvent the proliferation of the pathogen within host tissues. MAP and His kinases, downstream regulators, or master regulators that regulate expression of various virulence genes can also be targeted by synthetic or plant-based molecular inhibitors acting like fungicides. Other questions need to be addressed, such as which elicitors induce the ROS burst in resistant varieties and why preferred nitrogen sources repress virulence.

\section{ACKNOWLEDGMENTS}

We thank R. A. L. vander Hoorn, Department of Plant Sciences, University of Oxford, UK for help with the illustration and critical reading.

\section{LITERATURE CITED}

Anderson, J. P., Badruzsaufari, E., Schenk, P. M., Manners, J. M., Desmond, O. J., Ehlert, C., Maclean, D. J., Ebert, P. R., and Kazan, K. 2004. Antagonistic interaction between abscisic acid and jasmonate-ethylene signaling pathways modulates defense gene expression and disease resistance in Arabidopsis. Plant Cell 16:3460-3479.

Bae, H., Kim, M. S., Sicher, R. C., Bae, H. J., and Bailey, B. A. 2006. Necrosis- and ethylene-inducing peptide from Fusarium oxysporum induces a complex cascade of transcripts associated with signal transduction and cell death in Arabidopsis. Plant Physiol. 141:1056-1067.

Bednarek, P., Pislewska-Bednarek, M., Svatos, A., Schneider, B., Doubsky, J., Mansurova, M., Humphry, M., Consonni, C., Panstruga, R., SanchezVallet, A., Molina, A., and Schulze-Lefert, P. 2009. A glucosinolate metabolism pathway in living plant cells mediates broad-spectrum antifungal defense. Science 323:101-106.

Benhamou, N., Chamberland, H., and Pauz, J. F. 1990. Implication of pectic components in cell surface interactions between tomato root cells and Fusarium oxysporum f. sp. radicis-lycopersici. Plant Physiol. 92: 995-1003.

Berrocal-Lobo, M., and Molina, A. 2008. Arabidopsis defense response against Fusarium oxysporum. Trends Plant Sci. 13:145-150.

Bournival, B. L., Scott, J. W., and Vallejos, C. E. 1989. An isozyme marker for resistance to race 3 of Fusarium oxysporum f. sp. lycopersici in tomato. Theor. Appl. Genet. 78:489-494.

Brankovics, B., van Dam, P., Rep, M., de Hoog, G. S., van der Lee, T. A. J., Waalwijk, C., and van Diepeningen, A. D. 2017. Mitochondrial genomes reveal recombination in the presumed asexual Fusarium oxysporum species complex. BMC Genomics 18:735.

Bravo-Ruiz, G., Ruiz-Roldán, C., and Roncero, M. I. 2013. Lipolytic system of the tomato pathogen Fusarium oxysporum f. sp. lycopersici. Mol. Plant-Microbe Interact. 26:1054-1067.

Bu, Q., Jiang, H., Li, C. B., Zhai, Q., Zhang, J., Wu, X., Sun, J., Xie, Q., and Li, C. 2008. Role of the Arabidopsis thaliana NAC transcription factors ANAC019 and ANAC055 in regulating jasmonic acid-signaled defense responses. Cell Res. 18:756-767.

Calero-Nieto, F., Di Pietro, A., Roncero, M. I., and Hera, C. 2007. Role of the transcriptional activator $x \ln R$ of Fusarium oxysporum in regulation of xylanase genes and virulence. Mol. Plant-Microbe Interact. 20:977-985.

Can, C., Yucel, S., Korolev, N., and Katan, T. 2004. First report of fusarium crown and root rot of tomato caused by Fusarium oxysporum f. sp. radicis-lycopersici in Turkey. Plant Pathol. 53:814.

Cañero, D. C., and Roncero, M. I. 2008. Influence of the chloride channel of Fusarium oxysporum on extracellular laccase activity and virulence on tomato plants. Microbiology 154:1474-1481.

Caracuel, Z., Roncero, M. I., Espeso, E. A., González-Verdejo, C. I., GarcíaMaceira, F. I., and Di Pietro, A. 2003. The $\mathrm{pH}$ signalling transcription factor PacC controls virulence in the plant pathogen Fusarium oxysporum. Mol. Microbiol. 48:765-779.

Catanzariti, A. M., Lim, G. T., and Jones, D. A. 2015. The tomato I-3 gene: A novel gene for resistance to Fusarium wilt disease. New Phytol. 207: 106-118.

Chen, Y. C., Wong, C. L., Muzzi, F., Vlaardingerbroek, I., Kidd, B. N., and Schenk, P. M. 2014. Root defense analysis against Fusarium oxysporum reveals new regulators to confer resistance. Sci. Rep. 4: Article 5584.

Clay, N. K., Adio, A. M., Denoux, C., Jander, G., and Ausubel, F. M. 2009. Glucosinolate metabolites required for an Arabidopsis innate immune response. Science 323:95-101.

Cramer, R. A., Byrne, P. F., Brick, M. A., and Panella, L. 2003. Wickliffe E and Schwartz HF. Characterization of Fusarium oxysporum isolates from common bean and sugar beet using pathogenicity assays and random amplified polymorphic DNA markers. J. Phytopathol. 151:352-360.

Daami-Remadi, M., Ayed, F., Jebari, H., Jabnoun-Khiareddine, H., and Mahjoub, M. E. 2007. Variation among some Fusarium oxysporum f. sp melonis isolates by their effect on muskmelon plant growth and wilt severity. Afr. J. Plant Sci. Biotechnol. 1:5-9.

Dange, S. R., Desai, A. G., and Patel, S. I. 2006. Wilt of Castor and its management-A review. Agric. Rev. (Karnal) 27:147-151.

Dau, V. T., Burgess, L. W., Pham, L. T., Phan, H. T., Nguyen, H. D., Le, T. V., and Nguyen, D. H. 2009. First report of Fusarium wilt of watermelon in Vietnam. Australas. Plant Dis. Notes 4:1-3.

Davies, D. R., Bindschedler, L. V., Strickland, T. S., and Bolwell, G. P. 2006. Production of reactive oxygen species in Arabidopsis thaliana cell suspension cultures in response to an elicitor from Fusarium oxysporum: Implications for basal resistance. J. Exp. Bot. 57:1817-1827.

Dean, R., Van Kan, J. A., Pretorius, Z. A., Hammond-Kosack, K. E., Di Pietro, A., Spanu, P. D., Rudd, J. J., Dickman, M., Kahmann, R., Ellis, J., and Foster, G. D. 2012. The top 10 fungal pathogens in molecular plant pathology. Mol. Plant Pathol. 13:414-430.

Diener, A. C., and Ausubel, F. M. 2005. RESISTANCE TO FUSARIUM OXYSPORUM 1, a dominant Arabidopsis disease-resistance gene, is not race specific. Genetics 171:305-321.

Di Pietro, A., García-MacEira, F. I., Méglecz, E., and Roncero, M. I. 2001 A MAP kinase of the vascular wilt fungus Fusarium oxysporum is essential for root penetration and pathogenesis. Mol. Microbiol. 39: 1140-1152.

Dore, D. S. 2009. Grapevine rhizosphere bacteria: Influence of diversity and function on two root diseases. Master of Science thesis, Lincoln University, Canterbury, UK.

Dowd, C., Wilson, I. W., and McFadden, H. 2004. Gene expression profile changes in cotton root and hypocotyl tissues in response to infection with 
Fusarium oxysporum f. sp. vasinfectum. Mol. Plant-Microbe Interact. 17: 654-667.

du Toit, L. J., and Pelter, G. Q. 2003. Wilt of radish caused by Fusarium oxysporum f. sp. raphani in Washington State. Online publication. Plant Health Prog.. doi.org/10.1094/PHP-2003-061601-HN

Elliott, M. L., Des-Jardin, E. A., O’Donnell, K., Geiser, D. M., Harrison, N. A., and Broschat, T. K. 2010. Fusarium oxysporum f. sp. palmarum, a novel forma specialis causing a lethal disease of Syagrus romanzoffiana and Washingtonia robusta in Florida. Plant Dis. 94:31-38.

Endah, N. B. 2011. Investigating the mode of action of the mycoherbicide component Fusarium oxysporum f. sp. strigae on Striga parasitizing sorghum and its implication for Striga control in Africa. Ph.D. thesis, University of Hohenheim, Germany.

Epple, P., Apel, K., and Bohlmann, H. 1997. Overexpression of an endogenous thionin enhances resistance of Arabidopsis against Fusarium oxysporum. Plant Cell 9:509-520.

Garrido, C., González-Rodríguez, V. E., Carbú, M., Husaini, A. M., and Cantoral, J. M. 2016. Fungal diseases of strawberry and their diagnosis. Pages 157-195 in: Strawberry: Growth, Development and Diseases. A. M. Husaini and D. Neri, eds. CABI, Wallingford, UK.

Gonzalez-Cendales, Y., Catanzariti, A. M., Baker, B., McGrath, D. J., and Jones, D. A. 2016. Identification of I-7 expands the repertoire of genes for resistance to Fusarium wilt in tomato to three resistance gene classes. Mol. Plant Pathol. 17:448-463.

Gordon, T. R., and Martyn, R. D. 1997. The evolutionary biology of Fusarium oxysporum. Annu. Rev. Phytopathol. 35:111-128.

Grogan, R. G., and Kimble, K. A. 1959. The association of fusarium wilt with the asparagus decline and replant problem in California. Phytopathology 49:122-125.

Gupta, S., Bhar, A., and Das, S. 2013. Understanding the molecular defence responses of host during chickpea-Fusarium interplay: Where do we stand? Funct. Plant Biol. 40:1285-1297.

Hedge, V., Misra, R. S., and Jeeva, M. L. 2012. Sweet potato diseases: Diagnosis and management. Fruit. Veg. Cereal Sci. Biotechnol. 6:65-78.

Hemming, M. N., Basuki, S., McGrath, D. J., Carroll, B. J., and Jones, D. A 2004. Fine mapping of the tomato $I-3$ gene for fusarium wilt resistance and elimination of a co-segregating resistance gene analogue as a candidate for I-3. Theor. Appl. Genet. 109:409-418.

Henrique, F. H., Carbonell, S. A., Ito, M. F., Goncalves, J. G., Sasseron, G. R., and Chiorato, A. F. 2015. Classification of physiological races of Fusarium oxysporum f. sp. phaseoli in common bean. Bragantia 74 84-92.

Houterman, P. M., Cornelissen, B. J. C., and Rep, M. 2008. Suppression of plant resistance gene-based immunity by a fungal effector. PLoS Pathog. 4:e1000061-e1000066.

Huang, C. C., and Lindhout, P. 1997. Screening for resistance in wild Lycopersicon species to Fusarium oxysporum f. sp. lycopersici race 1 and race 2. Euphytica 93:145-153.

Hückelhoven, R. 2007. Cell wall-associated mechanisms of disease resistance and susceptibility. Annu. Rev. Phytopathol. 45:101-127.

Husaini, A. M. 2014. Challenges of climate change. GM Crops Food 5: 97-105.

Husaini, A. M., Kyoko, M., Chandrasekar, B., Kelly, S., Kaschani, F., Palmero, D., Jiang, J., Kaiser, M., Ahrazem, O., Overkleeft, H. S., and vander Hoorn, R. A. L. 2018. Multiplex fluorescent activity-based protein profiling identifies active $\alpha$-glycosidases and other hydrolases in plants. Plant Physiol. 177:24-37.

Ibtissem, H., Rezgui, S., Nabiha, B., and Cherif, M. 2014. Pathogenic and mating type characterization of an uncommon wilt disease of citrus in Tunisia. J. Phytopathol. Pest Manage. 1:34-45.

Inoue, I., Namiki, F., and Tsuge, T. 2002. Plant colonization by the vascular wilt fungus Fusarium oxysporum requires $F O W 1$, a gene encoding a mitochondrial protein. Plant Cell 14:1869-1883.

Ito, S., Ihara, T., Tamura, H., Tanaka, S., Ikeda, T., Kajihara, H., Dissanayake, C., Abdel-Motaal, F. F., and El-Sayed, M. A. 2007. $\alpha$-Tomatine, the major saponin in tomato, induces programmed cell death mediated by reactive oxygen species in the fungal pathogen Fusarium oxysporum. FEBS Lett. 581:3217-3222.

Jain, S., Akiyama, K., Kan, T., Ohguchi, T., and Takata, R. 2003. The G protein $\beta$ subunit FGB1 regulates development and pathogenicity in Fusarium oxysporum. Curr. Genet. 43:79-86.

Jain, S., Akiyama, K., Mae, K., Ohguchi, T., and Takata, R. 2002. Targeted disruption of a $\mathrm{G}$ protein $\alpha$ subunit gene results in reduced pathogenicity in Fusarium oxysporum. Curr. Genet. 41:407-413.

Jain, S., Akiyama, K., Takata, R., and Ohguchi, T. 2005. Signaling via the G protein $\alpha$ subunit FGA2 is necessary for pathogenesis in Fusarium oxysporum. FEMS Microbiol. Lett. 243:165-172.
Johnson, J. 1921. Fusarium-Wilt of Tobacco. J. Agric. Res. 20:515-536.

Joy, P. P., and Sherin, C. G. 2012. Pages 1-18 in: Diseases of Passion Fruit (Passiflora edulis): Pathogen, Symptoms, Infection, Spread and Management. Pineapple Research Station, Kerala Agriculture University, Vazhakulum, Kerala, India.

Kidd, B. N., Edgar, C. I., Kumar, K. K., Aitken, E. A., Schenk, P. M., Manners, J. M., and Kazan, K. 2009. The mediator complex subunit PFT1 is a key regulator of jasmonate-dependent defense in Arabidopsis. Plant Cell 21:2237-2252.

Kidd, B. N., Kadoo, N. Y., Dombrecht, B., Tekeoglu, M., Gardiner, D. M. Thatcher, L. F., Aitken, E. A., Schenk, P. M., Manners, J. M., and Kazan, K. 2011. Auxin signaling and transport promote susceptibility to the root-infecting fungal pathogen Fusarium oxysporum in Arabidopsis. Mol. Plant-Microbe Interact. 24:733-748.

Kim, Y. 2005. Characterization of California isolates of Fusarium oxysporum f. sp. vasinfectum. Plant Dis. 89:366-372.

Kraft, J. M., Haware, M. P., Halila, H., Sweetingham, M., and Bayaa, B. 2000. Soil borne diseases and their control. Pages 457-466 in: Linking Research and Marketing Opportunities for Pulses in the 21st Century. R. Knight, ed. Kluwer Academic Publishers, Dordrecht, The Netherlands.

Kumar, M., Tripathi, U. K., Tomer, A., Kumar, P., and Singh, A. 2014. Screening of linseed germplasm for resistance/tolerance against Fusarium oxysporum f. sp. lini (Bolley) disease. J. Plant Pathol. Microbiol. 5:235.

Laterrot, H. 1976. Mapping of I-2 allele in tomato, controlling the genetic resistance to pathotype 2 of Fusarium oxysporum f. sp. lycopersici wilt Ann. Amelior. Plant. 26:485-491.

Li, C.-y., Deng, G.-m., Yang, J., Viljoen, A., Jin, Y., Kuang, R.-b., Zuo, C.-w., Lv, Z.-c., Yang, Q.-s., Sheng, O., Wei, Y.-r., Hu, C.-h., Dong, T., and Yi, G.-j. 2012. Transcriptome profiling of resistant and susceptible Cavendish banana roots following inoculation with Fusarium oxysporum f. sp. cubense tropical race 4. BMC Genomics 13:374.

Lim, G. T. T., Wang, G. P., Hemming, M. N., Basuki, S., McGrath, D. J., Carroll, B. J., and Jones, D. A. 2006. Mapping the I-3 gene for resistance to Fusarium wilt in tomato: Application of an I-3 marker in tomato improvement and progress towards the cloning of I-3. Australas. Plant Pathol. 35:671-680.

Lim, G. T. T., Wang, G. P., Hemming, M. N., McGrath, D. J., and Jones, D. A. 2008. High resolution genetic and physical mapping of the I-3 region of tomato chromosome 7 reveals almost continuous microsynteny with grape chromosome 12 but interspersed microsynteny with duplications on Arabidopsis chromosomes 1, 2 and 3. Theor. Appl. Genet. 118:57-75.

Liu, F., Jiang, H., Ye, S., Chen, W. P., Liang, W., Xu, Y., Sun, B., Sun, J., Wang, Q., Cohen, J. D., and Li, C. 2010. The Arabidopsis P450 protein CYP82C2 modulates jasmonate-induced root growth inhibition, defense gene expression and indole glucosinolate biosynthesis. Cell Res. 20: 539-552.

López-Berges, M. S., Hera, C., Sulyok, M., Schäfer, K., Capilla, J., Guarro, J., and Di Pietro, A. 2013. The velvet complex governs mycotoxin production and virulence of Fusarium oxysporum on plant and mammalian hosts. Mol. Microbiol. 87:49-65.

López-Berges, M. S., Rispail, N., Prados-Rosales, R. C., and Di Pietro, A 2010. A nitrogen response pathway regulates virulence functions in Fusarium oxysporum via the protein kinase TOR and the bZIP protein MeaB. Plant Cell 22:2459-2475.

Ma, L.-J., Geiser, D. M., Proctor, R. H., Rooney, A. P., O’Donnell, K., Trail, F., Gardiner, D. M., Manners, J. M., and Kazan, K. 2013. Fusarium pathogenomics. Annu. Rev. Microbiol. 67:399-416.

Ma, L. J., van der Does, H. C., Borkovich, K. A., Coleman, J. J., Daboussi, M. J., Di Pietro, A., Dufresne, M., Freitag, M., Grabherr, M., Henrissat, B., Houterman, P. M., Kang, S., Shim, W. B., Woloshuk, C., Xie, X., Xu, J. R., Antoniw, J., Baker, S. E., Bluhm, B. H., Breakspear, A., Brown, D. W., Butchko, R. A., Chapman, S., Coulson, R., Coutinho, P. M., Danchin, E. G., Diener, A., Gale, L. R., Gardiner, D. M., Goff, S. Hammond-Kosack, K. E., Hilburn, K., Hua-Van, A., Jonkers, W., Kazan, K., Kodira, C. D., Koehrsen, M., Kumar, L., Lee, Y. H., Li, L., Manners, J. M., Miranda-Saavedra, D., Mukherjee, M., Park, G., Park, J., Park, S. Y., Proctor, R. H., Regev, A., Ruiz-Roldan, M. C., Sain, D., Sakthikumar, S., Sykes, S., Schwartz, D. C., Turgeon, B. G., Wapinski, I., Yoder, O., Young, S., Zeng, Q., Zhou, S., Galagan, J., Cuomo, C. A. Kistler, H. C., and Rep, M. 2010. Comparative genomics reveals mobile pathogenicity chromosomes in Fusarium. Nature 464:367-373.

Manzo, D., Ferriello, F., Puopolo, G., Zoina, A., D’Esposito, D., Tardella, L., Ferrarini, A., and Ercolano, M. R. 2016. Fusarium oxysporum f. sp. radicis-lycopersici induces distinct transcriptome reprogramming in resistant and susceptible isogenic tomato lines. BMC Plant Biol. 16:53

Martínez-Rocha, A. L., Roncero, M. I., López-Ramirez, A., Mariné, M. Guarro, J., Martínez-Cadena, G., and Di Pietro, A. 2008. Rho1 has 
distinct functions in morphogenesis, cell wall biosynthesis and virulence of Fusarium oxysporum. Cell. Microbiol. 10:1339-1351.

Marzluf, G. A. 1997. Genetic regulation of nitrogen metabolism in the fungi. Microbiol. Mol. Biol. Rev. 61:17-32.

McCain, A. H., and Noviello, C. 1985. Biological control of Cannabis sativus. Pages 635-642 in: Proc. VI Int. Symp. Biol. Control Weeds, Vancouver, Canada. E. S. Delfosse, ed.

McGrath, D., Gillespie, D., and Vawdrey, L. 1987. Inheritance of resistance to Fusarium oxysporum f. sp. lycopersici races 2 and 3 in Lycopersicon pennellii. Aust. J. Agric. Res. 38:729-733.

Michielse, C. B., van Wijk, R., Reijnen, L., Cornelissen, B. J. C., and Rep, M. 2009. Insight into the molecular requirements for pathogenicity of Fusarium oxysporum f. sp. lycopersici through large-scale insertional mutagenesis. Genome Biol. 10:R4.

Muthamilarasan, M., and Prasad, M. 2013. Plant innate immunity: An updated insight into defense mechanism. J. Biosci. 38:433-449.

Namiki, F., Matsunaga, M., Okuda, M., Inoue, I., Nishi, K., Fujita, Y., and Tsuge, T. 2001. Mutation of an arginine biosynthesis gene causes reduced pathogenicity in Fusarium oxysporum f. sp. melonis. Mol. PlantMicrobe Interact. 14:580-584.

Niño-Sánchez, J., Casado-Del Castillo, V., Tello, V., De Vega-Bartol, J. J., Ramos, B., Sukno, S. A., and Díaz Mínguez, J. M. 2016. The FTF gene family regulates virulence and expression of SIX effectors in Fusarium oxysporum. Mol. Plant Pathol. 17:1124-1139.

Nirmaladevi, D., Venkataramana, M., Srivastava, R. K., Uppalapati, S. R., Gupta, V. K., Yli-Mattila, T., Clement Tsui, K. M., Srinivas, C. Niranjana, S. R., and Chandra, N. S. 2016. Molecular phylogeny, pathogenicity and toxigenicity of Fusarium oxysporum $\mathrm{f}$. sp. lycopersici. Sci. Rep. 6: Article 21367.

Nita-Lazar, M., Heyraud, A., Gey, C., Braccini, I., and Lienart, Y. 2004. Novel oligosaccharides isolated from Fusarium oxysporum L. rapidly induce PAL activity in Rubus cells. Acta Biochim. Pol. 51:625-647.

Nucci, M., and Anaissie, E. 2007. Fusarium infections in immunocompromised patients. Clin. Microbiol. Rev. 20:695-704.

Ogawa, T., Pan, L., Kawai-Yamada, M., Yu, L.-H., Yamamura, S., Koyama, T., Kitajima, S., Ohme-Takagi, M., Sato, F., and Uchimiya, H. 2005. Functional analysis of Arabidopsis ethylene-responsive element binding protein conferring resistance to Bax and abiotic stress-induced plant cell death. Plant Physiol. 138:1436-1445.

Paddock, E. F. 1950. A tentative assignment of the Fusarium immunity locus to linkage group 5 in tomato. Genetics 35:683-684.

Pennyacker, B. W., and Nelson, P. E. 1972. Histopathology of carnation infected with Fusarium oxysporum f. sp. dianthi. Phytopathology 62:1318-1326.

Panthee, D. R., and Chen, F. 2010. Genomics of fungal disease resistance in tomato. Curr. Genomics 11:30-39.

Pataky, N. R. 1988. Report on Plant Disease No. 6. Department of Crop Sciences, University of Illinois, Urbana-Champaign.

Pérez-Nadales, E., and Di Pietro, A. 2011. The membrane mucin Msb2 regulates invasive growth and plant infection in Fusarium oxysporum. Plant Cell 23:1171-1185.

Perez-Nadales, E., and Di Pietro, A. 2015. The transmembrane protein Sho1 cooperates with the mucin Msb2 to regulate invasive growth and plant infection in Fusarium oxysporum. Mol. Plant Pathol. 16:593-603.

Pfalz, M., Vogel, H., and Kroymann, J. 2009. The gene controlling the indole glucosinolate modifier 1 quantitative trait locus alters indole glucosinolate structures and aphid resistance in Arabidopsis. Plant Cell 21:985-999.

Rabiei-Motlagh, E., Falahati-Rastegar, M. H., Jafarpour, R. B., and Jahanbakhsh, V. 2010. Root diseases of onion caused by some root colonizing fungi in north east of Iran. Am.-Eur. J. Agric. Environ. Sci. 7:484-491.

Ramos, B., Alves-Santos, F. M., García-Sánchez, M. A., Martín-Rodrigues, N., Eslava, A. P., and Díaz-Mínguez, J. M. 2007. The gene coding for a new transcription factor ( $\mathrm{ftf} 1$ ) of Fusarium oxysporum is only expressed during infection of common bean. Fungal Genet. Biol. 44:864-876.

Remadi, M. D., Sayes, S., Raouani, N. H., and Hassine, W. H. 2009. Effects of Verticillium dahliae Kleb., Fusarium oxysporum Schlecht. f. sp. tuberosi Snyder, Hansen and Meloidogyne javanica (Treub.) Chitwood inoculated individually or in combination on potato growth, wilt severity and nematode development. Afr. J. Microbiol. 3:595-604.

Rep, M., van der Does, H. C., Meijer, M., van Wijk, R., Houterman, P. M. Dekker, H. L., de Koster, C. G., and Cornelissen, B. J. C. 2004. A small, cysteine-rich protein secreted by Fusarium oxysporum during colonization of xylem vessels is required for $I-3$-mediated resistance in tomato. Mol. Microbiol. 53:1373-1383.

Reyes, A. A., and Chadha, K. C. 1972. Interaction between Fusarium oxysporum f. sp. coglutinans and turnip mosaic virus in Brassica compestris var. chinensis seedlings. Phytopathology 62:1424-1428.

Rispail, N., and Di Pietro, A. 2009. Fusarium oxysporum Ste12 controls invasive growth and virulence downstream of the Fmk1 MAPK cascade. Mol. Plant-Microbe Interact. 22:830-839.

Rispail, N., and Di Pietro, A. 2010. The two-component histidine kinase Fhk1 controls stress adaptation and virulence of Fusarium oxysporum. Mol. Plant Pathol. 11:395-407.

Ruiz-Roldán, C., Pareja-Jaime, Y., González-Reyes, J. A., and Roncero, M. I. 2015. The transcription factor Con7-1 is a master regulator of morphogenesis and virulence in Fusarium oxysporum. Mol. Plant-Microbe Interact. 28:55-68.

Sarfatti, M., Abu-Abied, M., Katan, J., and Zamir, D. 1991. RFLP mapping of $I 1$, a new locus in tomato conferring resistance against Fusarium oxysporum f. sp. lycopersici race 1. Theor. Appl. Genet. 82:22-26.

Scott, J. C., Kirkpatrick, S. C., and Gordon, T. R. 2010. Variation in susceptibility of lettuce cultivars to fusarium wilt caused by Fusarium oxysporum f. sp. lactucae. Plant Pathol. 59:139-146.

Scott, J. W., and Jones, J. P. 1989. Monogenic resistance in tomato to Fusarium oxysporum f. sp. lycopersici race 3. Euphytica 40:49-53.

Sela-Buurlage, M. B., Budai-Hadrian, O., Pan, Q., Carmel-Goren, L., Vunsch, R., Zamir, D., and Fluhr, R. 2001. Genome-wide dissection of Fusarium resistance in tomato reveals multiple complex loci. Mol. Genet. Genomics 265:1104-1111.

Silverstein, K. A., Graham, M. A., Paape, T. D., and VandenBosch, K. A. 2005. Genome organization of more than 300 defensin-like genes in Arabidopsis. Plant Physiol. 138:600-610.

Stipes, R. J., and Phipps, P. M. 1975. Fusarium oxysporum f. sp. perniosum on Fusarium-wilted Mimosa trees. Phytopathology 65:188-190.

Stoilova, T., and Chavdarov, P. 2006. Evaluation of lentil germplasm for disease resistance to Fusarium wilt (Fusarium oxysporum f. sp. lentis). J. Cent. Eur. Agric. 7:121-126.

Thatcher, L. F., Manners, J. M., and Kazan, K. 2009. Fusarium oxysporum hijacks COI1-mediated jasmonate signaling to promote disease development in Arabidopsis. Plant J. 58:927-939.

van der Does, H. C., Fokkens, L., Yang, A., Schmidt, S. M., Langereis, L., Lukasiewicz, J. M., Hughes, T. R., and Rep, M. 2016. Transcription factors encoded on core and accessory chromosomes of Fusarium oxysporum induce expression of effector genes. PLoS Genet. 12: e 1006401

van der Weerden, N. L., Lay, F. T., and Anderson, M. A. 2008. The plant defensin, NaD1, enters the cytoplasm of Fusarium oxysporum hyphae. J. Biol. Chem. 283:14445-14452.

Wang, S., and McKie, P. 2007. Monitoring Fusarium Wilt of Canary Island Date Palm: A Guideline for State Inspectors and Nursery/Landscape Professionals. Pages 1-3 in: Plant Dis. Alert 001. Plant Pathology Program, Nevada Department of Agriculture. http://agri.nv.gov/uploadedFiles/ agrinvgov/Content/Plant/Plant_Pathology/MonitoringFusariumWiltofCanary IslandDatePalm.pdf

Weimer, J. L. 1928. A Wilt disease of alfalfa caused by Fusarium oxysporum var. medicaginis, N. Var. J. Agric. Res. 37:419-433.

Widmann, C., Gibson, S., Jarpe, M. B., and Johnson, G. L. 1999. Mitogenactivated protein kinase: Conservation of a three-kinase module from yeast to human. Physiol. Rev. 79:143-180.

Woloshuk, C. P., and Kolattukudy, P. E. 1986. Mechanism by which contact with plant cuticle triggers cutinase gene expression in the spores of Fusarium solani f. sp. pisi. Proc. Natl. Acad. Sci. USA 83:1704-1708.

Wong, K. H., Hynes, M. J., and Davis, M. A. 2008. Recent advances in nitrogen regulation: A comparison between Saccharomyces cerevisiae and filamentous fungi. Eukaryot. Cell 7:917-925.

Zhu, Q. H., Stephen, S., Taylor, J., Helliwell, C. A., and Wang, M. B. 2014 Long noncoding RNAs responsive to Fusarium oxysporum infection in Arabidopsis thaliana. New Phytol. 201:574-584.

Zhu, Q. H., Stephen, S., Kazan, K., Jin, G., Fan, L., Taylor, J., Dennis, E. S. Helliwell, C. A., and Wang, M. B. 2013. Characterization of the defense transcriptome responsive to Fusarium oxysporum-infection in Arabidopsis using RNA-seq. Gene 512:259-266. 